\title{
Correlations and Path Analysis Studies on Yield and its Components in Mungbean (Vigna radiata (L.) Wilczek)
}

\author{
Rupal Dhoot ${ }^{1}$, K.G. Modha ${ }^{1}$, Dhirendra Kumar ${ }^{1}$ and Meenakshi Dhoot ${ }^{2}$ \\ ${ }^{1}$ Department of Genetics and Plant Breeding, Navsari Agricultural University, \\ Navsari-396450, Gujarat, India \\ ${ }^{2}$ Department of Plant Breeding and Genetics, MPUAT, Udaipur-313001, Rajasthan, India \\ *Corresponding author
}

\begin{abstract}
A B S T R A C T

\begin{tabular}{|l|}
\hline Keyw or d s \\
Mungbean, \\
$\begin{array}{l}\text { Correlation } \\
\text { coefficient and } \\
\text { path analysis. }\end{array}$ \\
\hline Article Info \\
\hline $\begin{array}{l}\text { Accepted: } \\
\text { 04 April } 2017 \\
\text { Available Online: } \\
\text { 10 May } 2017\end{array}$ \\
\hline
\end{tabular}

The present research work was carried out at Navsari Agricultural University, Navsari during the summer 2014 to study correlation among quantitative traits and their direct and indirect effect on seed yield in $\mathrm{F}_{2}$ populations (Meha X Pusa Vishal, Meha X GM-4) of mungbean. Correlation analysis revealed that seed yield was significantly and positively correlated with pods per plants and harvest index in $\mathrm{F}_{2}$ population of Meha X Pusa Vishal and with plant height, primary branches per plant, clusters per plant, pods per plant, straw yield per plant and harvest index in $\mathrm{F}_{2}$ population of Meha X GM-4. It indicates that an association of two characters is not only due to genes but also due to their influence of the environment. The path coefficient analysis on phenotypic basis revealed that pods per plant, plant height, clusters per plant, seeds per pod, 100 seed weight, straw yield per plant and harvest index had positive direct effect and primary branches per plant had negative direct effects on seed yield in both the populations, indicated that pods per plant directly lead to increase in seed yield.
\end{abstract}

\section{Introduction}

Mungbean (Vigna radiata $\mathrm{L}$. Wilczek) is a short duration legume crop cultivated primarily for their dry seeds. Annual mungbean production in India is around 1.61 million tonnes from about 3.38 million ha area (Anon., 2013-2014). The crops are utilized in several ways, where seeds, sprouts and young pods are consumed as sources of protein, amino acids, vitamins and minerals, and plant parts are used as fodder and green manure. Mungbean protein is easily digested without flatulence. They have ability to fix atmospheric nitrogen (N2) in symbiosis with the soil bacteria Rhizobium spp. They can be grown successfully in extreme environments (e.g., high temperatures, low rain fall, and poor soils) with few economic inputs (Das et al., 2014). The quantitative characters are the best indicators of yield. Yield is a complex character which is affected by a number of component characters and the surrounding environments. Thus, selection for grain yield becomes difficult unless the associations between yield contributing characters are known. The statistics which measure the degree and direction of association between two or more variable is known as correlation. Measurement of correlation helps to identify the relative contribution of component characters towards yield (Panse, 1957). 
Indirect selection through component character with high heritability is advantageous for polygenic character like yield. Correlation between different characters is an aspect which should be kept in mind for better planning of selection programs. Path analysis is carried out using the estimates of correlation coefficients. Path analysis gives idea about direct and indirect influences of each of the component characters towards dependent trait.

\section{Materials and Methods}

The present research work was carried out at Navsari Agricultural University, Navsari during the summer 2014. We included $2 \mathrm{~F}_{2}$ populations of mungbean (Meha X Pusa Vishal, Meha $\mathrm{X}$ GM-4) in this study. Experiment was conducted in non-replicated trial as it was segregating material. Each row consisted of 20 plants with spacing of $45 \mathrm{~cm} \mathrm{x}$ $15 \mathrm{~cm}$ inter and intra row spacing. Each $F_{2}$ was raised with minimum of 300 plant population and individual plant observations were recorded from 100 randomly selected plants. Observations were recorded for following traits i.e. Days to flowering, Plant height $(\mathrm{cm})$, Days to maturity, Primary branches per plant, Clusters per plant, Pods per plant, Seeds per pod, 100-seed weight (g), Seed yield per plant (g), Straw Yield (g) and Harvest index (\%). The simple correlations (phenotypic) between different characters were estimated according to Weber and Moorthy (1952) and path-coefficient analysis was carried out following Dewey and Lu (1959).

\section{Results and Discussion}

In the present study, seed yield per plant recorded significant and positive correlation with pods per plant and harvest index in $F_{2}$ population of Meha X Pusa Vishal (Table 1). These results are in close agreement with earlier workers Khajudparn and Tantasawat (2011), Kumar et al., (2010 ), Tabasum et al., (2010), Srivastava and Singh (2012), Gadakh et al., (2013), Prasanna et al., (2013), Javed et al., (2014) for pods per plant and Singh et al., (2009) for harvest index. While in F2 population of Meha X GM-4 it showed significant and positive correlation with plant height, primary branches per plant, clusters per plant, pods per plant, straw yield per plant and harvest index (Table 2). There are in agreement with the results reported by Tabasum et al., (2010) and Javed et al., (2014) for plant height; Khajudparn and Tantasawat (2011), Gadakh et al., (2013), Prasanna et al., (2013) for primary branches per plant; Tabasum et al., (2010), Khajudparn and Tantasawat (2011), Gadakh et al., (2013), Prasanna et al., (2013) for clusters per plant; Khajudparn and Tantasawat (2011), Kumar et al., (2010), Tabasum et al., (2010), Srivastava and Singh (2012), Gadakh et al., (2013), Prasanna et al., (2013), Javed et al., (2014) for pods per plant and (Singh et al., 2009) for harvest index. It indicates that an association of two characters is not only due to genes but also due to their influence of the environment. Hence, simultaneous selection based on these characters could be suggested for improvement of yield in segregating populations.

Path coefficient analysis accommodates assistance for categorizing the total correlation into direct and indirect effects. The results of path analysis showed table 3 and figure $1\left(\mathrm{~F}_{2}\right.$ of Meha $\mathrm{X}$ Pusa Vishal) and table 4 and figure 2 ( $F_{2}$ of Meha X GM-4). In both the $F_{2}$ populations pods per plant had maximum and positive direct effect on seed yield. Some other characters like plant height, clusters per plant, seeds per pod, 100 seed weight, straw yield per plant and harvest index also had positive direct effect in both the population. 
Table.1 Phenotypic correlation coefficients of seed yield per plant with other characters in $F_{2}$ population of Meha x Pusa Vishal in mungbean

\begin{tabular}{|c|c|c|c|c|c|c|c|c|c|c|c|}
\hline Characters & DF & PH & PB & DM & $\mathbf{C P}$ & $\mathbf{P P}$ & SP & $100 \mathrm{SW}$ & ST Y & HI & SY \\
\hline DF & 1.0000 & & & & & & & & & & \\
\hline PH & $0.2820 * *$ & 1.0000 & & & & & & & & & \\
\hline PB & 0.0775 & 0.1163 & 1.0000 & & & & & & & & \\
\hline DM & $0.6987 * *$ & $0.4357 * *$ & -0.0249 & 1.0000 & & & & & & & \\
\hline $\mathbf{C P}$ & 0.1745 & $0.2478^{*}$ & $0.4523^{* *}$ & 0.0258 & 1.0000 & & & & & & \\
\hline $\mathbf{P P}$ & 0.0991 & 0.1069 & -0.0296 & -0.0361 & 0.0069 & 1.0000 & & & & & \\
\hline SP & $-0.2102 *$ & -0.1480 & -0.1190 & -0.1807 & 0.0056 & $-0.2343^{*}$ & 1.0000 & & & & \\
\hline $100 \mathrm{SW}$ & -0.0326 & 0.0897 & -0.0763 & 0.0658 & 0.0254 & -0.0041 & 0.0198 & 1.0000 & & & \\
\hline ST Y & 0.0584 & 0.0637 & -0.1207 & 0.0269 & $-0.2206^{*}$ & 0.1359 & -0.0571 & 0.1537 & 1.0000 & & \\
\hline HI & -0.0059 & -0.0559 & 0.0948 & -0.0942 & 0.1692 & $0.3324 * *$ & 0.0838 & -0.1204 & $-0.7164 * *$ & 1.0000 & \\
\hline SY & 0.0644 & 0.1129 & -0.0559 & -0.0898 & 0.0739 & $0.8794 * *$ & -0.0427 & 0.0525 & 0.0804 & $0.4215^{* *}$ & 1.0000 \\
\hline
\end{tabular}

Table.2 Phenotypic correlation coefficients of seed yield per plant with other characters in $\mathrm{F}_{2}$ population of Meha x GM-4 in mungbean

\begin{tabular}{|c|c|c|c|c|c|c|c|c|c|c|c|}
\hline Characters & DF & PH & PB & DM & $\mathbf{C P}$ & $\mathbf{P P}$ & SP & $100 \mathrm{SW}$ & ST Y & HI & SY \\
\hline DF & 1.0000 & & & & & & & & & & \\
\hline $\mathbf{P H}$ & $0.3434 * *$ & 1.0000 & & & & & & & & & \\
\hline PB & $-0.3373 * *$ & 0.0138 & 1.0000 & & & & & & & & \\
\hline DM & $0.5884 * *$ & $0.2164 *$ & $-0.3100 * *$ & 1.0000 & & & & & & & \\
\hline $\mathbf{C P}$ & $-0.2584 *$ & 0.0912 & $0.6479 * *$ & -0.1188 & 1.0000 & & & & & & \\
\hline PP & -0.0576 & $0.2076 *$ & $0.3300 * *$ & -0.1291 & $0.3544 * *$ & 1.0000 & & & & & \\
\hline SP & 0.0369 & -0.0998 & -0.1117 & -0.0040 & -0.1460 & $-0.2476^{*}$ & 1.0000 & & & & \\
\hline $100 \mathrm{SW}$ & 0.1109 & 0.0289 & -0.1318 & 0.1407 & -0.1205 & -0.0332 & 0.0041 & 1.0000 & & & \\
\hline ST Y & -0.0944 & $0.2902 * *$ & 0.1551 & -0.0628 & $0.3349 * *$ & $0.3559 * *$ & 0.0254 & 0.0182 & 1.0000 & & \\
\hline HI & 0.1154 & -0.1811 & 0.0587 & -0.0144 & -0.1069 & $0.3544 * *$ & -0.0841 & 0.0813 & $-0.6212 * *$ & 1.0000 & \\
\hline SY & -0.0307 & $0.2252 *$ & $0.3237 * *$ & -0.1009 & $0.3725 * *$ & $0.9249 * *$ & -0.0182 & 0.1282 & $0.3868 * *$ & $0.3538 * *$ & 1.0000 \\
\hline
\end{tabular}


Table.3 Path coefficient analysis of component characters towards seed yield per plant in $\mathrm{F}_{2}$ population of Meha $x$ Pusa Vishal in mungbean

\begin{tabular}{|c|c|c|c|c|c|c|c|c|c|c|c|}
\hline Characters & DF & $\mathbf{P H}$ & $\mathbf{P B}$ & DM & $\mathbf{C P}$ & $\mathbf{P P}$ & SP & $100 \mathrm{SW}$ & ST Y & HI & $\begin{array}{c}\text { Phenotypic } \\
\text { correlation } \\
\text { with seed } \\
\text { yield } \\
\end{array}$ \\
\hline DF & 0.0356 & 0.0173 & -0.0048 & -0.0539 & 0.0117 & 0.0771 & -0.0253 & -0.0018 & 0.0101 & -0.0016 & 0.0644 \\
\hline PH & 0.0100 & 0.0612 & -0.0072 & -0.0336 & 0.0166 & 0.0831 & -0.0178 & 0.0049 & 0.0110 & -0.0153 & 0.1129 \\
\hline PB & 0.0028 & 0.0071 & -0.0617 & 0.0019 & 0.0302 & -0.023 & -0.0143 & -0.0041 & -0.0209 & 0.0260 & -0.0559 \\
\hline DM & 0.0249 & 0.0267 & 0.0015 & -0.0772 & 0.0017 & -0.0281 & -0.0217 & 0.0036 & 0.0047 & -0.0258 & -0.0898 \\
\hline $\mathbf{C P}$ & 0.0062 & 0.0152 & -0.0279 & -0.0020 & 0.0668 & 0.0053 & 0.0007 & 0.0014 & -0.0382 & 0.0464 & 0.0739 \\
\hline $\mathbf{P P}$ & 0.0035 & 0.0065 & 0.0018 & 0.0028 & 0.0005 & 0.7779 & -0.0282 & -0.0002 & 0.0235 & 0.0912 & $0.8794 * *$ \\
\hline $\mathbf{S P}$ & -0.0075 & -0.0091 & 0.0073 & 0.0140 & 0.0004 & -0.1822 & 0.1202 & 0.0011 & -0.0099 & 0.0230 & -0.0427 \\
\hline $100 \mathrm{SW}$ & -0.0012 & 0.0055 & 0.0047 & -0.0051 & 0.0017 & -0.0032 & 0.0024 & 0.0541 & 0.0266 & -0.0330 & 0.0525 \\
\hline ST Y & 0.0021 & 0.0039 & 0.0074 & -0.0021 & -0.0147 & 0.1058 & -0.0069 & 0.0083 & 0.1732 & -0.1966 & 0.0804 \\
\hline HI & -0.0002 & -0.0034 & -0.0058 & 0.0073 & 0.0113 & 0.2585 & 0.0101 & -0.0065 & -0.1241 & 0.2744 & $0.4215^{* *}$ \\
\hline
\end{tabular}


Table.4 Path coefficient analysis of component characters towards seed yield per plant in $\mathrm{F}_{2}$ population of Meha x GM-4 in mungbean

\begin{tabular}{|c|c|c|c|c|c|c|c|c|c|c|c|}
\hline Characters & DF & PH & PB & DM & CP & PP & SP & $100 \mathrm{SW}$ & ST Y & HI & $\begin{array}{c}\text { Phenotypic } \\
\text { correlation } \\
\text { with seed } \\
\text { yield } \\
\end{array}$ \\
\hline DF & -0.0138 & 0.0199 & 0.0008 & 0.0018 & -0.0242 & -0.0466 & 0.0079 & 0.0161 & -0.0156 & 0.0228 & -0.0307 \\
\hline $\mathbf{P H}$ & -0.0047 & 0.0579 & 00.00 & 0.0007 & 0.0085 & 0.1680 & -0.0213 & 0.0042 & 0.0478 & -0.0358 & $0.2252 *$ \\
\hline PB & 0.0047 & 0.0008 & -0.0025 & -0.0010 & 0.0606 & 0.2670 & -0.0239 & -0.0192 & 0.0256 & 0.0116 & $0.3237 * *$ \\
\hline DM & -0.0081 & 0.0125 & 0.0008 & 0.0031 & -0.0111 & -0.1045 & -0.0009 & 0.0205 & -0.0103 & -0.0029 & -0.1009 \\
\hline $\mathbf{C P}$ & 0.0036 & 0.0053 & -0.0016 & -0.0004 & 0.0935 & 0.2868 & -0.0312 & -0.0175 & 0.0552 & -0.0211 & $0.3725 * *$ \\
\hline $\mathbf{P P}$ & 0.0008 & 0.0120 & -0.0008 & -0.0004 & 0.0331 & 0.8092 & -0.0529 & -0.0048 & 0.0586 & 0.0701 & $0.9249 * *$ \\
\hline SP & -0.0005 & -0.0058 & 0.0003 & 00.00 & -0.0137 & -0.2003 & 0.2137 & 0.0006 & 0.0042 & -0.0166 & -0.0182 \\
\hline $100 \mathrm{SW}$ & -0.0015 & 0.0017 & 0.0003 & 0.0004 & -0.0113 & -0.0269 & 0.0009 & 0.1455 & 0.0030 & 0.0161 & 0.1282 \\
\hline ST Y & 0.0013 & 0.0168 & -0.0004 & -0.0002 & 0.0313 & 0.2880 & 0.0054 & 0.0026 & 0.1648 & -0.1229 & $0.3868 * *$ \\
\hline HI & -0.0016 & -0.0105 & -0.0001 & 00.00 & -0.0100 & 0.2868 & -0.0180 & 0.0118 & -0.1024 & 0.1978 & $0.3538 * *$ \\
\hline
\end{tabular}

** - Significant at 1.0 per cent level of probability, * - Significant at 5.0 per cent level of probability

Residual $=0.0559$

Bold diagonal figures are the direct effect

DF - Days to flowering

PB - Primary Branches per plant

SP - Seeds per pod

ST Y - Straw yield per plant (g)
PH - Plant height ( $\mathrm{cm})$

CP - Clusters per plant

$100 \mathrm{SW}-100$-seed weight (g)

HI - Harvest index (\%)
DM - Days to maturity

PP - Pods per plant

SY - Seed yield per plant (g) 
Fig.1 Diagramatic presentation of factors influencing seed yield in mungbean $\left(\mathrm{F}_{2}\right.$ generation of Meha $\mathrm{x}$ Pusa Vishal)

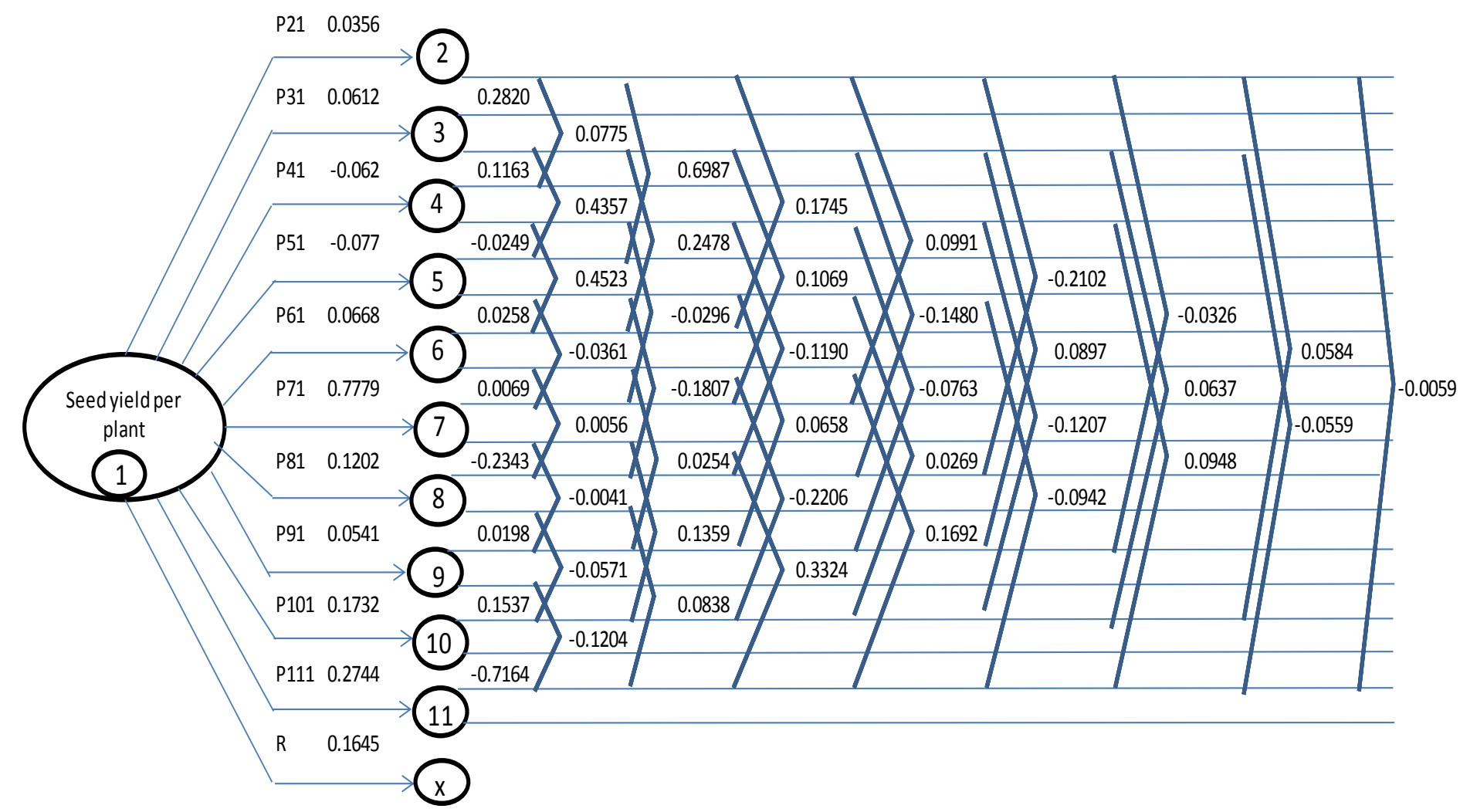

Single arrow represents direct effect, cross lines joining horizontal lines represent indirect effect and $\mathrm{R}$ represents residual effect. 
Fig.2 Diagramatic presentation of factors influencing seed yield in mungbean ( $\mathrm{F}_{2}$ generation of Meha $\mathrm{x}$ GM-4)

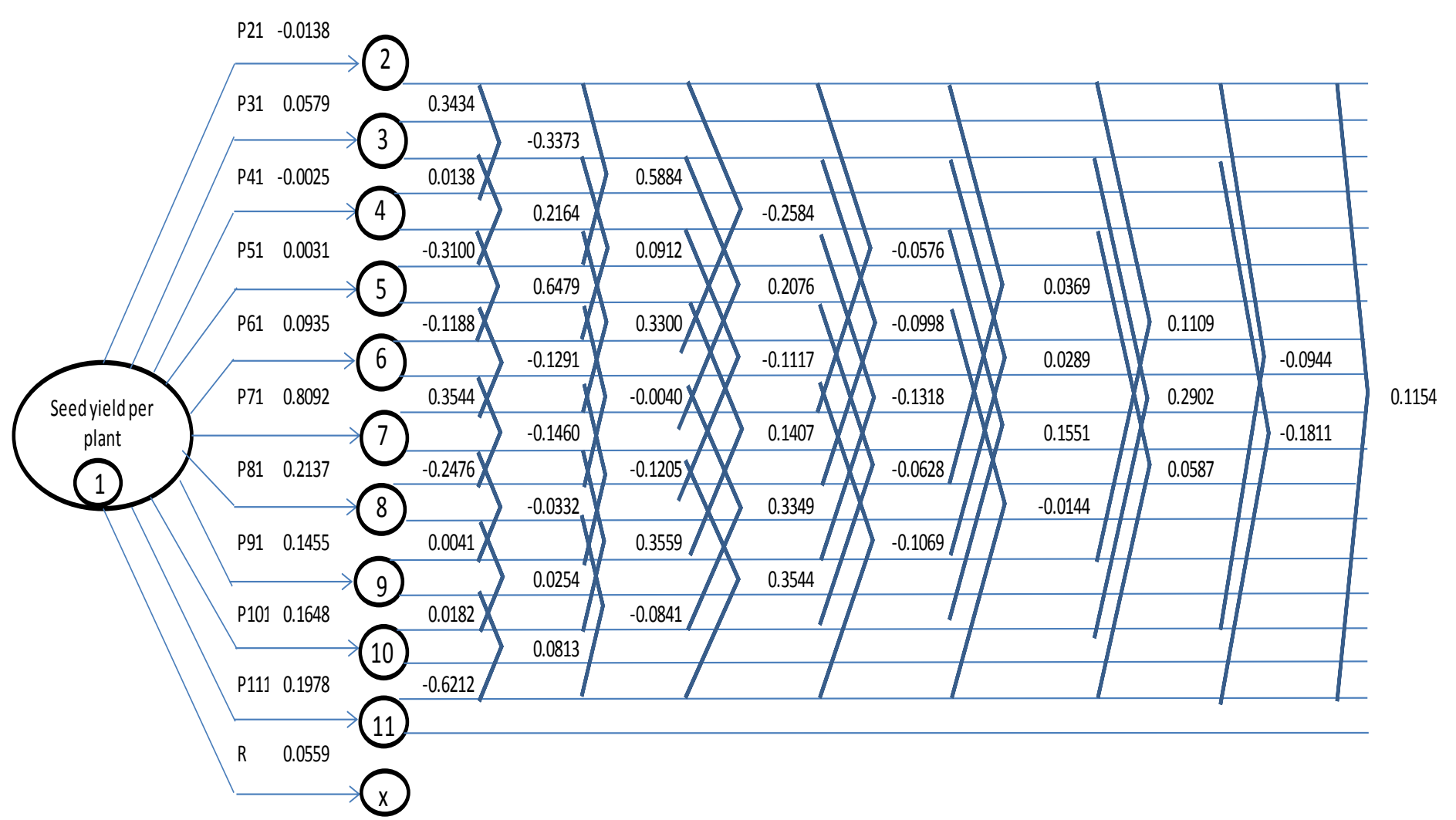

Single arrow represents direct effect, cross lines joining horizontal lines represent indirect effect and $\mathrm{R}$ represents residual effect. 
The negative direct effects on seed yield by primary branches per plant in both the populations. The results are in accordance with Kumar et al., $\left(2010^{\mathrm{b}}\right)$, Vyas (2010), Srivastava and Singh (2012), Prasanna et al., (2013) for plant height; Tabasum et al., (2010), Vyas (2010), Khajudparn and Tantasawat (2011), Prasanna et al., (2013) for primary branches per plant; Singh et al., (2009), Vyas (2010), Khajudparn and Tantasawat (2011), Gadakh et al., (2013), clusters per plant; Kumar et al., (2010), Tabasum et al., (2010), Khajudparn and Tantasawat (2011), Srivastava and Singh (2012), Gadakh et al., (2013), Prasanna et al., (2013) for pods per plant; Singh et al., (2009), Kumar et al., $\left(2010^{\mathrm{b}}\right)$, Khajudparn and Tantasawat (2011), Srivastava and Singh (2012), Gadakh et al., (2013), Prasanna et al., (2013) for seeds per pod; Singh et al., (2009), Tabasum et al., (2010), Vyas (2010), Khajudparn and Tantasawat (2011), Srivastava and Singh (2012), Gadakh et al., (2013), prasanna et al., (2013) for 100 seed weight; Kumar et al., $\left(2010^{b}\right)$, Tabasum et al., (2010), Vyas (2010), Gadakh et al., (2013), Prasanna et al., (2013) for harvest index. But days to flowering shows negative direct effect in $\mathrm{F}_{2}$ of Meha X Pusa Vishal (Kumar et al., 2010 and Prasanna et al., 2013)and positive direct effect in $\mathrm{F}_{2}$ of Meha X GM-4 (Singh et al., 2009; Vyas, 2010; Srivastava and Singh, 2012 and Gadakh et al., 2013) while for days to maturity shows positive direct effect in $\mathrm{F}_{2}$ of Meha X Pusa Vishal (Kumar et al., 2010 and Prasanna et al., 2013) and negative direct effect in $\mathrm{F}_{2}$ of Meha X GM-4 (Singh et al., 2009 and Gadakh et al., 2013). Path analysis revealed that number of pods per plant had high direct effect, therefore, simple selection for this character would be useful to maximum seed yield. Considering all the aspects together it is apparent from path analysis that maximum effects as well as appreciable indirect influences were exerted by pods per plant, clusters per plant, straw yield per plant and harvest index. These characters also exhibited significant and positive association with seed yield per plant. Hence, they may be considered as the most important yield contributing characters and appropriate prominence should be placed on these components while breeding for high yielding types in mungbean.

\section{References}

Anonymous. 2011-2012. http://www.iipr.res.in/e-pulse-databook.html

Das, S., Das, S.S. and Ghosh, P. 2014. A comparative analysis of genetic diversity across certain mung bean and urd bean cultivars of West Bengal, using ISSR markers. Asian J. Plant Sci. Res., 4: 56 - 61.

Deway, D.R. and Lu, K.H. 1959. A correlation and path coefficient analysis of components of crested wheat grass seed production. Agron. J., 51: 515-518.

Gadakh, S.S., Dethe, A.M. and Kathale, M.N. 2013. Genetic variability, correlations and path analysis studies on yield and its components in mungbean [Vigna radiata (L.) Wilczek]. Bioinfolet, 10(2A): $441-447$.

Javed, I., Ahmad, H. M., Ahsan, M., Ali, Q., Ghani, M. U., Iqbal, M. S., Rashid, M., and Akram, H.N. 2014. Induced genetic variability by gamma radiation and traits association study in mungbean (Vigna radiata L.). Life Sci. J., 11(8s): 530-539.

Khajudparn, P., and Tantasawat, P. 2011. Relationships and variability of agronomic and physiological characters in mungbean. African J. Biotechnol., 10(49): 9992-10000.

Kumar, N.V., Lavanya, G.R., Singh, S.K. and Pandey, P. 2010. Genetic association and path coefficient analysis in mungbean [Vigna radiate (L.) Wilczek]. 
AAB Bioflux, 2(3): 251-258.

Prasanna, B.L., Rao, P.J.M., Murthy, K.G.K. and Prakash, K.K. 2013. Genetic variability, correlation and path coefficient analysis in mungbean. Environ. Ecol., 31(4): 1782-1788.

Singh, S.K., Singh, I.P., Singh, B.B. and Singh, O. 2009. Correlation and path coefficient studies for yield and its components in mungbean (Vigna radiate (L.) Wilczek). Legume Res., 32(3): 180-185.

Srivastava, R.L. and Singh, G. 2012. Genetic variability, correlation and path analysis in mungbean [Vigna radiate (L.) Wilczek]. Indian J. L. Sci., 2(1): 61-65.
Tabasum, A., Saleem, M. and Aziz, I. 2010. Genetic variability, trait association and path analysis of yield and yield components in Mungbean (Vigna radiata (L.)Wilczek). Pak. J. Bot., 42(6): 3915-3924.

Vyas, Priyanka. 2010. Character Association and Path Analysis under Two Environments in Mungbean (Vigna radiate (L.) Wilczek). Trends Biosci., 3(1): 88-90.

Weber, C.R. and Moorthy, B.R. 1952. Heritable and non-heritable relationship and variabilities of oil content and organic character in $\mathrm{F}_{2}$ generation of soybean crosses. Agron. J., 44: 202-209.

\section{How to cite this article:}

Rupal Dhoot, K.G. Modha, Dhirendra Kumar and Meenakshi Dhoot. 2017. Correlations and Path Analysis Studies on Yield and its Components in Mungbean (Vigna radiata (L.) Wilczek). Int.J.Curr.Microbiol.App.Sci. 6(5): 370-378. doi: http://dx.doi.org/10.20546/ijcmas.2017.605.042 